\title{
Enhancing Coriander (Coriandrum sativum L.) Yield through Integration of Chemical Fertilizers, Enriched Compost and Biofertilizers
}

\author{
R. K. Mathukia*, M.V. Adhithi, K.V. Hirapara and P. R. Surya \\ Department of Agronomy, College of Agriculture, Junagadh Agricultural University, \\ Junagadh-362001, Gujarat, India \\ *Corresponding author
}

Keywords

Coriander, Azotobacter, phosphate solubilizing bacteria (PSB), potash solubilizing bacteria

\section{Article Info}

Accepted:

18 May 2020

Available Online:

10 June 2020

\section{A B S T R A C T}

A field experiment was conducted on medium black calcareous clayey soil at Junagadh (Gujarat) during rabiseason of 2017-18 to study the effect of integration of chemical fertilizers, enriched compost and biofertilizers on growth and yield of coriander (Coriandrum sativum L.). The experimental results revealed that significantly higher values of growth parameters viz., plant height, number of branches per plant, and dry matter production, and yield attributes viz., number of umbels per plant, number of umbellates per umbel, number of seeds per umbellate, and test weight along with higher stover yield $(1688 \mathrm{~kg} / \mathrm{ha})$ were recorded with application ofenriched compost + recommended dose of fertilizers (RDF) + vesicular-arbuscular mycorrhizae (VAM). Whereas, significantly higher seed yield (14.93 q/ha), nutrient uptake by plant, available $\mathrm{N}, \mathrm{P}, \mathrm{K}$ in soil after harvest along with higher net return (₹ 69434/ha) and B:C ratio (2.81) were realized with the application of RDF + VAM + Azotobacter+ phosphate solubilizing bacteria (PSB) + potash mobilizing bacteria $(\mathrm{KMB})$.Based on the results, it could be concluded that higher production and net returns from coriander can be obtained by the application of RDF (60-60-40 N-P $\mathrm{P}_{2} \mathrm{O}_{5^{-}}$ $\mathrm{K}_{2} \mathrm{O} \mathrm{kg} / \mathrm{ha}$ ) + soil application of Azotobacter + PSB + KMB each @ $3 \mathrm{~L} / \mathrm{ha}+\mathrm{VAM}$ @ $0.25 \mathrm{~kg} / \mathrm{ha}$.

\section{Introduction}

Coriander is one of the oldest known seed spices used by mankind as a condiment throughout the world. India is the largest producer of coriander both in terms of area $(6,72,760$ ha) and production $(8,63,530$ tonnes) with an average productivity of 1303 $\mathrm{kg} / \mathrm{ha}$. It is cultivated as commercial crop in Rajasthan, Gujarat, Tamil Nadu, Madhya Pradesh, Andhra Pradesh, Uttar Pradesh and
Haryana. In Gujarat, coriander is the most important spice crop and cultivated in $1,21,200$ ha which produces $1,89,520$ tonnes with productivity of $1,563 \mathrm{~kg} / \mathrm{ha}$ (Anon., 2017).

Since coriander is low water requiring, remunerative and short duration crop, farmers of Saurashtra region are attracted towards its cultivation in rabi season. Despite concerted efforts, productivity of this crop is almost 
stagnant, which is a matter of great concern. Extensive use of chemical fertilizers has an adverse effect on soil and human health.

Dependence on chemical fertilizers and chemical pesticides for the future agricultural growth will result in further loss of soil quality, acidification of soil, possibility of ground water contamination and hence loss of ecological balance.

Integrated nutrient management has currently attained a special significance in crop production to address the sustainability problem and tremendous success has been achieved in several crops. Application of biofertilizers such as Azospirillum, Azotobacter, Rhizobium, PSB, KMB, etc. has led to a decrease in the use of chemical fertilizers and has provided high quality organic products free of harmful agrochemical residues for human safety.

The effect of mycorrhizae in increasing plant growth has been well documented by many workers for many crops. Mycorrhizal fungi may improve soil phosphorus availability by solubilizing inorganic forms of phosphorus or by mineralization of organic phosphorus. Compost can be enriched by superphosphate, bone meal or rock phosphate, N-fixing, Psolubilizing and $\mathrm{K}$ mobilizing cultures, cellulolytic microorganisms,micro nutrients, and biocontrol microbial cultures.

In addition to improving availability of plant nutrients, these additions help to reduce the composting time considerably and increase population of microorganisms.

Taking note of the facts highlighted above, a field experiment was conducted to study the effect of integration of chemical fertilizers, enriched compost and biofertilizers on growth and yield of coriander and post-harvest soil fertility.

\section{Materials and Methods}

A field experiment was conducted on a medium black clayey soil at Instructional Farm, Department of Agronomy, College of Agriculture, Junagadh Agricultural University, Junagadh (Gujarat) in rabi season of 2017-18. Geographically, Junagadh is situated at $21.5^{\circ} \mathrm{N}$ latitude and $70.5^{\circ} \mathrm{E}$ longitude with an altitude of $60 \mathrm{~m}$ above the mean sea level. The experimental soil was slightly alkaline in reaction with $\mathrm{pH} 7.67$ and EC $0.52 \mathrm{dS} / \mathrm{m}$, low in available nitrogen $(245$ $\mathrm{kg} / \mathrm{ha}$ ), medium in available phosphorus (35 $\mathrm{kg} / \mathrm{ha}$ ) and medium in available potash (271 $\mathrm{kg} / \mathrm{ha}$ ). The mean maximum and minimum temperature during the crop period ranged from 27.0 to 37.3 and 10.0 to $20.3^{\circ} \mathrm{C}$, respectively. During the crop period, the relative humidity was in the range of 47 to $74 \%$ (RH I) and 20 to 63\% (RH II). Bright sun shine hours, wind velocity and daily evaporation was 1.5 to $9.2 \mathrm{~h} /$ day, 2.8 to 6.4 $\mathrm{km} / \mathrm{h}$ and 2.8 to $7.7 \mathrm{~mm} /$ day, respectively. Winter rainfall occurred during first week of December and second week of February.

The experiment comprising 10 treatmentsviz., $\mathrm{T}_{1}$ : RDF (60-60-40 kg N-P $\mathrm{O}_{5}-\mathrm{K}_{2} \mathrm{O} / \mathrm{ha}, \mathrm{T}_{2}$ : VAM soil application @ $0.25 \mathrm{~kg} / \mathrm{ha}, \mathrm{T}_{3}$ : Azotobacter + PSB + KMB soil application each@3 L/ha, T4: RDF + VAM, T5: VAM + Azotobacter +PSB + KMB, $\mathrm{T}_{6}: \mathrm{RDF}+\mathrm{VAM}$ + Azotobacter $+\mathrm{PSB}+\mathrm{KMB}, \mathrm{T}_{7}: 75 \% \mathrm{RDF}$ $+\mathrm{VAM}+$ Azotobacter + PSB + KMB, $\mathrm{T}_{8}$ : $50 \% \mathrm{RDF}+\mathrm{VAM}+$ Azotobacter + PSB + $\mathrm{KMB}, \mathrm{T}_{9}$ : Enriched compost @ 5 t/ha + VAM and $\mathrm{T}_{10}$ :Enriched compost @ $5 \mathrm{t} / \mathrm{ha}+\mathrm{RDF}+$ VAM, was laid out inrandomized block design with three replications.

The coriander variety ' $\mathrm{GC} 2$ ' was sown on November 21, 2017 at row spacing of $30 \mathrm{~cm}$ using seed rate of $15 \mathrm{~kg} / \mathrm{ha}$. The gross and net plot size was $5.0 \mathrm{~m} \mathrm{x} 3.0 \mathrm{~m}$ and $4.0 \mathrm{~m} \times 1.8$ $\mathrm{m}$, respectively. 
As per the treatments, nitrogen was applied in two equal splits at sowing and 25 DAS in form of urea. Entire dose of phosphorus and potash as per treatments was applied in form of diammonium phosphate and muriate of potash, respectively at sowing. Liquid formulation of Azotobacter (Azotobacter chroococcum), PSB (Pseudomonas striata) and KSB (Frateuria aurantia) and powder formulation of VAM (Glomus fasciculatum) having $1 \mathrm{x} \quad 10^{6} \mathrm{cfu} / \mathrm{g}$ were used as soil application. Azotobacter, PSB and KMB each @ 3 L/ha and VAM @ $0.25 \mathrm{~kg} / \mathrm{ha}$ were applied to soil and thoroughly incorporated in to soil at the time of sowing of the coriander. Microbial enriched compost was obtained from KRIBHCO. The compost was readily enriched with specific strains of $\mathrm{N}$ fixers, PSB and cellulolytic microorganisms. The enriched compost containing 1.6-2.5\% N, 1.8 $2.0 \% \mathrm{P}$ and $1-1.6 \% \mathrm{~K}$ was applied just before sowing as per the treatments.

The crop was raised as per the recommended package of practices. The crop was harvested at physiological maturity on February 23, 2018. The growth and yield attributes were recorded from the five tagged plants in each plot. Seed and stover yield were recorded from the net plot area and converted into quintal per hectare base. Soil and plant analysis was carried out adopting standard methods (Jackson, 1974).

The expenses incurred for all the cultivation operations from preparatory tillage to harvesting including the cost of inputs viz., seeds, compost, biofertilizers, fertilizers, irrigation, pesticides, etc. applied to each treatment was calculated on the basis of prevailing local charges. The gross realization in terms of rupees per hectare was worked out taking into consideration the seed and stover yields from each treatment and local market prices.Net return of each treatment was calculated by deducting the total cost of cultivation from the gross returns. The benefit:cost ratio (B:C) was calculated by dividing gross return with cost of cultivation.

\section{Results and Discussion}

The results revealed that different treatments manifested significant influence ongrowth and yield of coriander (Table 1). The treatment $\mathrm{T}_{10}$ (Enriched compost $+\mathrm{RDF}+$ VAM) recorded significantly the highest plant height $(44.77 \mathrm{~cm})$,number of branches per plant (6.07) and dry matter per plant (17.67 g), but it remained statistically equivalent to the treatments $\mathrm{T}_{9}($ Enriched compost $+\mathrm{VAM})$ and $\mathrm{T}_{6}(\mathrm{RDF}+\mathrm{VAM}+$ Azotobacter $+\mathrm{PSB}+$ $\mathrm{KMB}$ ) in case of plant height and number of branches per plant, and with the treatments $\mathrm{T}_{9}$ (Enriched compost $\left.+\mathrm{VAM}\right), \mathrm{T}_{6}(\mathrm{RDF}+$ $\mathrm{VAM}+$ Azotobacter $+\mathrm{PSB}+\mathrm{KMB})$ and $\mathrm{T}_{4}(\mathrm{RDF}+\mathrm{VAM})$ in case of dry matter. This might be due to adequate supply of $\mathrm{N}, \mathrm{P}$ and $\mathrm{K}$ during the plant growth period through chemical fertilizers and improved physical, chemical and biological properties of soil with enriched compost. Microbial cultures enriched with compost and VAM might have increased the availability of nutrients in the rhizosphere. These results confirm the findings of Pandey et al., (2014), Lokhande et al., (2015), Matama and Parvatam (2016).

An appraisal of data (Table 1) indicated that significantly the most number of umbels per plant (10.83),number of umbellates per umbel (6.00), number of seeds per umbellate(6.07) and test weight(14.84 g) was recorded with the treatment $\mathrm{T}_{10}$ (Enriched compost $+\mathrm{RDF}+$ VAM), which remained statistically at par with the treatments $\mathrm{T}_{9}$ (Enriched compost + $\mathrm{VAM}), \mathrm{T}_{6}(\mathrm{RDF}+\mathrm{VAM}+$ Azotobacter $+\mathrm{PSB}$ $+\mathrm{KMB})$ and $\mathrm{T}_{4}(\mathrm{RDF}+\mathrm{VAM})$ in respect of number of umbels/plant, with the treatment $\mathrm{T}_{9}$ (Enriched compost + VAM) in case of umbellates/umbel and number of seeds per umbellate, and with the treatments 
$\mathrm{T}_{9}($ Enriched compost $+\mathrm{VAM})$ and $\mathrm{T}_{6}(\mathrm{RDF}+$ $\mathrm{VAM}+$ Azotobacter $+\mathrm{PSB}+\mathrm{KMB})$ in respect of test weight. A scrutiny of data (Table 1) further revealed that application of $\mathrm{RDF}+\mathrm{VAM}+$ Azotobacter + PSB + KMB $\left(\mathrm{T}_{6}\right)$ established its superiority by producing significantly the highest seed yield (14.93q/ha), however it was found statistically at par with the treatments $\mathrm{T}_{10}$ (Enriched compost $+\mathrm{RDF}+\mathrm{VAM}), \mathrm{T}_{1}(\mathrm{RDF}), \mathrm{T}_{7}(75 \%$ $\mathrm{RDF}+\mathrm{VAM}+$ Azotobacter + $\mathrm{PSB}+\mathrm{KMB})$ and $\mathrm{T}_{4}(\mathrm{RDF}+\mathrm{VAM})$. The extent of increase in seed yield with the treatments $\mathrm{T}_{6}, \mathrm{~T}_{10}, \mathrm{~T}_{1}$, $\mathrm{T}_{7}$ and $\mathrm{T}_{4}$ was 34.14, 27.58, 22.55, 22.01 and 21.56 per cent, respectively over the treatment $\mathrm{T}_{2}$ (VAM).

Significantly the highest stover yield $(16.88 \mathrm{q} / \mathrm{ha})$ was registered under the treatment $\mathrm{T}_{10}$ (Enriched compost $+\mathrm{RDF}+$ VAM) and it was found statistically at par with the treatments $\mathrm{T}_{9}$ (Enriched compost + $\mathrm{VAM}), \mathrm{T}_{6}(\mathrm{RDF}+\mathrm{VAM}+$ Azotobacter $+\mathrm{PSB}$ $+\mathrm{KMB}), \mathrm{T}_{4}(\mathrm{RDF}+\mathrm{VAM})$ and $\mathrm{T}_{1}(\mathrm{RDF})$. The magnitude of increase in stover yield with the treatments $\mathrm{T}_{10}, \mathrm{~T}_{9}, \mathrm{~T}_{6}, \mathrm{~T}_{4}$ and $\mathrm{T}_{1}$ was 39.27, $34.57,32.10,30.86$ and 27.39 per cent, respectively over the treatment $\mathrm{T}_{2}$ (VAM).

The beneficial effects of enriched compost, inorganic fertilizer and biofertilizer application on yield and yield attributes seems to be due to better growth of plants in terms of dry matter accumulation owing to favourable soil physical, chemical and biological properties.

The increase in seed yield was attributed to remarkable improvement in almost all the growth and yield attributes under these treatments. Positive response of coriander crop in terms of yield attributes and yield to inorganic fertilizer, enriched compost and biofertilizers have also been reported by Lokhande et al., (2015), Kumar et al., (2016) and Datta et al., (2017).
The data given in Table 2 showed that application of RDF + VAM + Azotobacter + $\mathrm{PSB}+\mathrm{KMB}\left(\mathrm{T}_{6}\right)$ recorded significantly the highest uptake of nitrogen $(64.60 \mathrm{~kg} / \mathrm{ha})$, phosphorus $(8.61 \mathrm{~kg} / \mathrm{ha})$ and potassium (49.97 $\mathrm{kg} / \mathrm{ha}$ ), but remained statistically at par with the treatments $\mathrm{T}_{8}(50 \% \mathrm{RDF}+\mathrm{VAM}+$ Azotobacter + PSB + KMB $)$ andT 7 (75\% RDF $+\mathrm{VAM}+$ Azotobacter $+\mathrm{PSB}+\mathrm{KMB})$ in case of $\mathrm{N}$ and $\mathrm{K}$ uptake, and with the treatment $\mathrm{T}_{7}(75 \% \mathrm{RDF}+\mathrm{VAM}+$ Azotobacter $+\mathrm{PSB}+$ $\mathrm{KMB})$ in respect of $\mathrm{K}$ uptake.

It can be attributed to higher content of $\mathrm{N}, \mathrm{P}$ and $\mathrm{K}$ in coriander with application of RDF, biofertilizers and VAM due to increased nutrients availability owing to better physical, chemical and biological properties of soil under these treatments.

Moreover, higher yield with these treatments ultimately resulted in higher uptake of nutrients. The present findings are within the close vicinity of those reported by Abou-Aly and Gomma (2002), Pramanik and Singh (2003) and Sharma and Abrol (2007).

The data furnished in Table 2 indicated that significantly the highest organic carbon content $(0.87 \%)$ was recorded under the treatment $\mathrm{T}_{9}$ (Enrich compost $\left.+\mathrm{VAM}\right)$, but it was statistically at par with the treatments $\mathrm{T}_{10}($ Enriched compost $+\mathrm{RDF}+\mathrm{VAM})$ and $\mathrm{T}_{8}$ $(50 \% \mathrm{RDF}+\mathrm{VAM}+$ Azotobacter $+\mathrm{PSB}+$ $\mathrm{KMB})$. The treatment $\mathrm{T}_{3}$ (Azotobacter $+\mathrm{PSB}$ $+\mathrm{KMB})$ recorded significantly the lowest organic carbon content $(0.56 \%)$.

Ample supply organic matter through enriched compost and inoculation of biofertilizers to the soil provides a congenial environment in rhizosphere for vigorous root growth and microbial population, this might have increased the organic carbon content. Similar results were also reported by Ahmad et al., (2008). 
Table.1 Growth and yield of coriander under integrated nutrient management treatments

\begin{tabular}{|c|c|c|c|c|c|c|c|c|c|}
\hline Treatment & $\begin{array}{c}\text { Plant } \\
\text { height } \\
(\mathrm{cm})\end{array}$ & $\begin{array}{l}\text { Branches } \\
\text { /plant }\end{array}$ & $\begin{array}{c}\text { Dry } \\
\text { matter/p } \\
\text { lant (g) }\end{array}$ & $\begin{array}{l}\text { Umbel } \\
\text { s /plant }\end{array}$ & $\begin{array}{l}\text { Umbellates } \\
\text { /umbel }\end{array}$ & $\begin{array}{c}\text { Seeds/ } \\
\text { umbellate }\end{array}$ & $\begin{array}{c}\text { Test } \\
\text { weight }\end{array}$ & $\begin{array}{c}\text { Seed } \\
\text { yield } \\
\text { (q/ha) }\end{array}$ & $\begin{array}{c}\text { Stover } \\
\text { yield } \\
\text { (q/ha) }\end{array}$ \\
\hline $\mathrm{T}_{1}: \mathrm{RDF}$ & 41.87 & 4.67 & 16.20 & 10.07 & 5.45 & 5.52 & 14.45 & 13.64 & 15.44 \\
\hline$T_{2}: \quad$ VAM & 34.27 & 3.80 & 14.40 & 9.13 & 4.91 & 4.92 & 13.49 & 11.13 & 12.12 \\
\hline $\mathrm{T}_{3}:$ Azotobacter + PSB + KMB & 36.90 & 4.00 & 15.47 & 9.57 & 5.23 & 5.33 & 13.91 & 11.69 & 13.74 \\
\hline $\mathrm{T}_{4}: \mathrm{RDF}+\mathrm{VAM}$ & 42.47 & 4.87 & 17.00 & 10.27 & 5.60 & 5.54 & 14.53 & 13.53 & 15.86 \\
\hline $\begin{array}{c}\mathrm{T}_{5}: \quad \mathrm{VAM}+\text { Azotobacter }_{\text {KMB }} \text { PSB }+ \\
\text { KMB }\end{array}$ & 34.80 & 4.00 & 14.73 & 9.47 & 5.00 & 5.09 & 13.69 & 12.29 & 13.14 \\
\hline $\begin{array}{c}\mathrm{T}_{6}: \quad \mathrm{RDF}+\mathrm{VAM}+\text { Azotobacter }+ \\
\mathrm{PSB}+\mathrm{KMB}\end{array}$ & 42.80 & 5.13 & 17.30 & 10.37 & 5.62 & 5.65 & 14.61 & 14.93 & 16.01 \\
\hline $\begin{array}{l}\mathrm{T}_{7}: \quad 75 \% \mathrm{RDF}+\mathrm{VAM}+ \\
\text { Azotobacter + PSB + KMB }\end{array}$ & 40.20 & 4.57 & 15.87 & 9.93 & 5.34 & 5.50 & 14.41 & 13.58 & 15.20 \\
\hline $\begin{array}{c}\mathrm{T}_{8}: 50 \% \mathrm{RDF}+\mathrm{VAM}+ \\
\text { Azotobacter + PSB + KMB }\end{array}$ & 39.03 & 4.33 & 15.17 & 9.63 & 5.30 & 5.33 & 14.25 & 12.81 & 13.83 \\
\hline T9: Enriched compost + VAM & 43.77 & 5.27 & 17.47 & 10.63 & 5.79 & 5.85 & 14.80 & 12.31 & 16.31 \\
\hline $\begin{array}{c}\text { T }_{10}: \text { Enriched compost }+ \text { RDF }+ \\
\text { VAM }\end{array}$ & 44.77 & 6.07 & 17.67 & 10.83 & 6.00 & 6.07 & 14.84 & 14.20 & 16.88 \\
\hline S.Em.土 & 0.74 & 0.32 & 0.28 & 0.20 & 0.11 & 0.14 & 0.10 & 0.51 & 0.55 \\
\hline $\mathrm{CD}(\mathrm{P}=\mathbf{0 . 0 5})$ & 2.21 & 0.94 & 0.83 & 0.60 & 0.31 & 0.41 & 0.30 & 1.50 & 1.62 \\
\hline
\end{tabular}


Table.2 Nutrients uptake, post-harvest soil fertility and economics under integrated nutrient management treatments

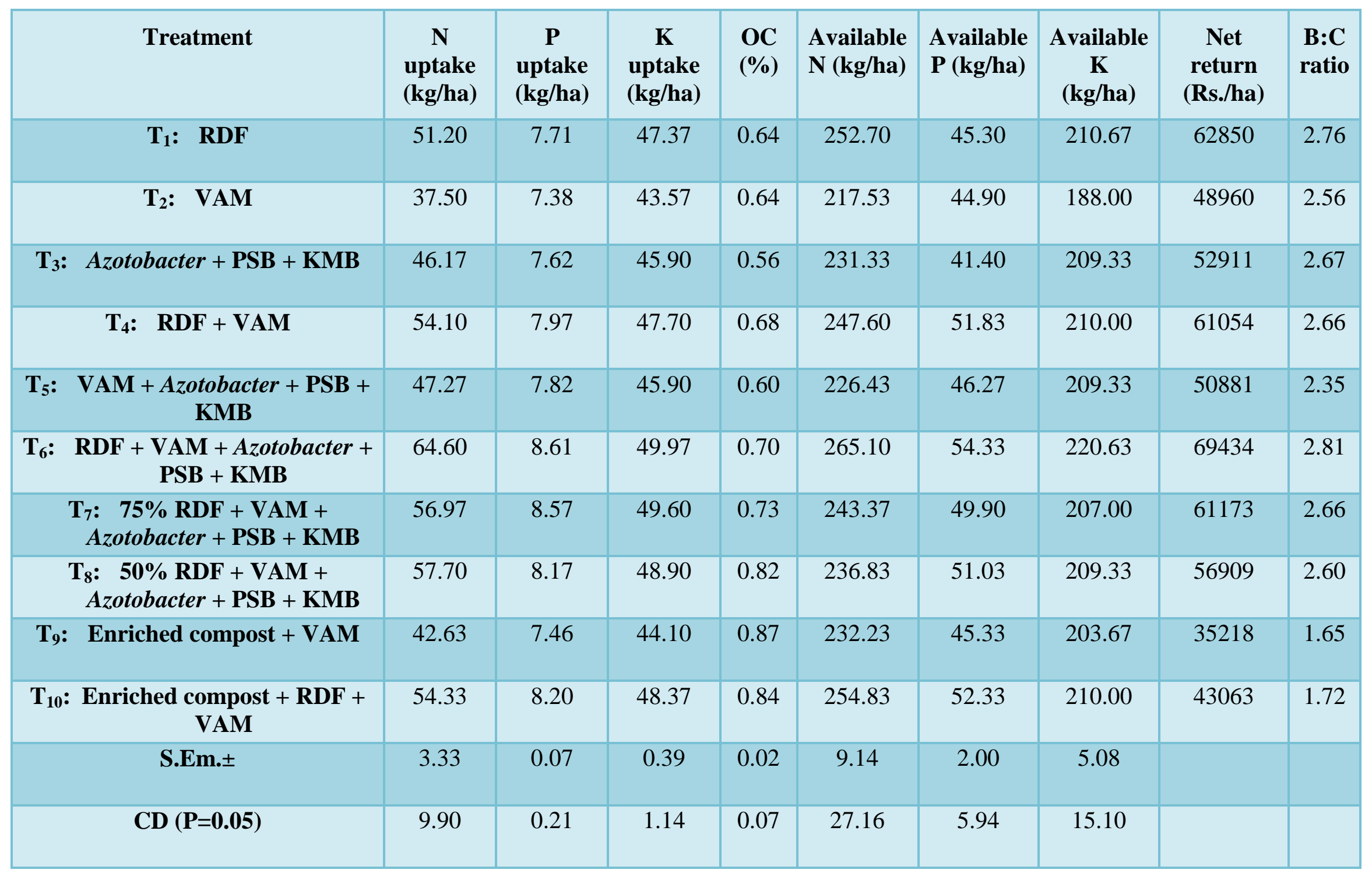


Significantly the highest available N (265.10 $\mathrm{kg} / \mathrm{ha}$ ) was recorded under the treatment $\mathrm{T}_{6}$ $(\mathrm{RDF}+\mathrm{VAM}+$ Azotobacter $+\mathrm{PSB}+\mathrm{KMB})$, but it was statistically at par with treatments $\mathrm{T}_{10}$ (Enriched compost $\left.+\mathrm{RDF}+\mathrm{VAM}\right)$, $\mathrm{T}_{1}(\mathrm{RDF}), \mathrm{T}_{4}(\mathrm{RDF}+\mathrm{VAM})$ and $\mathrm{T}_{7}(75 \%$ $\mathrm{RDF}+\mathrm{VAM}+$ Azotobacter + PSB + KMB $)$. The treatment $\mathrm{T}_{2}$ (VAM) recorded significantly the lowest available N (217.53 $\mathrm{kg} / \mathrm{ha}$ ).

Significantly the highest available $\mathrm{P}_{2} \mathrm{O}_{5}$ $(54.33 \mathrm{~kg} / \mathrm{ha})$ was noted with the treatment $\mathrm{T}_{6}$ $(\mathrm{RDF}+\mathrm{VAM}+$ Azotobacter $+\mathrm{PSB}+\mathrm{KMB})$, which was remained statistically at par with the treatments $\mathrm{T}_{10}$ (Enriched compost $+\mathrm{RDF}+$ $\mathrm{VAM}), \mathrm{T}_{4}(\mathrm{RDF}+\mathrm{VAM}), \mathrm{T}_{8}(50 \% \mathrm{RDF}+$ $\mathrm{VAM}+$ Azotobacter $+\mathrm{PSB}+\mathrm{KMB})$ and $\mathrm{T}_{7}(75 \% \mathrm{RDF}+\mathrm{VAM}+$ Azotobacter $+\mathrm{PSB}+$ $\mathrm{KMB})$. While, the lowest available $\mathrm{P}_{2} \mathrm{O}_{5}$ $(44.90 \mathrm{~kg} / \mathrm{ha})$ was analysed with the treatment $\mathrm{T}_{2}$ (VAM).

Application of RDF +VAM + Azotobacter + $\mathrm{PSB}+\mathrm{KMB}\left(\mathrm{T}_{6}\right)$ resulted in significantly the highest available $\mathrm{K}_{2} \mathrm{O}(220.63 \mathrm{~kg} / \mathrm{ha})$ and it was found statistically at par with the treatments $\mathrm{T}_{1}(\mathrm{RDF}), \mathrm{T}_{4}(\mathrm{RDF}+\mathrm{VAM})$, $\mathrm{T}_{10}($ Enriched compost $+\mathrm{RDF}+\mathrm{VAM})$, $\mathrm{T}_{8}(50 \% \mathrm{RDF}+\mathrm{VAM}+$ Azotobacter $+\mathrm{PSB}+$ $\mathrm{KMB}), \mathrm{T}_{3}$ (Azotobacter $\left.+\mathrm{PSB}+\mathrm{KMB}\right)$, $\mathrm{T}_{5}(\mathrm{VAM}+$ Azotobacter $+\mathrm{PSB}+\mathrm{KMB})$ and $\mathrm{T}_{7}(75 \% \mathrm{RDF}+\mathrm{VAM}+$ Azotobacter $+\mathrm{PSB}+$ $\mathrm{KMB})$. Conversely, the treatment $\mathrm{T}_{2}(\mathrm{VAM})$ registered significantly the lowest available $\mathrm{K}_{2} \mathrm{O}(188.00 \mathrm{~kg} / \mathrm{ha})$.

Application of recommended dose of chemical fertilizers might have supplied the nutrients in sufficient amount required by the plant for its growth and development.

Application of biofertilizers as supplements might have enhanced the nutrient availability by releasing or solubilizing the soil nutrients which are in fixed and unavailable forms.
Hence, after harvest, higher amount of soil nutrients might have been observed with combination of biofertilizers with chemical fertilizers.

The data on economics (Table 2) revealed that the maximum net returns of Rs. 69434/ha was realized with treatment $\mathrm{T}_{6}(\mathrm{RDF}+\mathrm{VAM}+$ Azotobacter + PSB + KMB), followed by the treatments $\mathrm{T}_{1}(\mathrm{RDF})$ and $\mathrm{T}_{7}(75 \% \mathrm{RDF}+$ $\mathrm{VAM}+$ Azotobacter + PSB + KMB) having net return of Rs. 62850 and Rs. 61173/ha, respectively. Whereas, the lowest net realization of Rs. 35218/ha was accrued under $\mathrm{T}_{9}($ Enriched compost + VAM $)$.

The data (Table 2) further indicated that the highest B:C (2.81) was obtained with the treatment $\mathrm{T}_{6}(\mathrm{RDF}+\mathrm{VAM}+$ Azotobacter + PSB + KMB), followed by the treatments $\mathrm{T}_{1}(\mathrm{RDF})$ with $\mathrm{B}: \mathrm{C}$ ratio of 2.76 and $\mathrm{T}_{3}($ Azotobacter $+\mathrm{PSB}+\mathrm{KMB})$ with $\mathrm{B}: \mathrm{C}$ of 2.67 .

While, the lowest $\mathrm{B}: \mathrm{C}$ ratio (1.65) was accrued with the treatment $\mathrm{T}_{9}$ (Enriched compost $+\mathrm{VAM})$. The highest net return and $\mathrm{B}: \mathrm{C}$ ratio gained in the treatment $\mathrm{T}_{6}$ is mainly due to increased seed and stover yield over other treatments.

These results are in conformity with those reported by Ali et al., (1994), Gupta and Gangwar (2012) and Jhankar et al., (2017).

Based on the experimental results, it seems quite logical to conclude that higher production and net return from coriander (Gujarat Coriander 2) can be obtained by the integrated application of recommended dose of fertilizers (60-60-40 N- $\left.\mathrm{P}_{2} \mathrm{O}_{5}-\mathrm{K}_{2} \mathrm{O} \mathrm{kg} / \mathrm{ha}\right)+$ soil application of Azotobacter + PSB + KMB each @ 3 L/ha + VAM @ 0.25 kg/ha on medium black calcareous clayey soil under South Saurashtra Agro-Climatic Zone. 


\section{References}

Abou-Aly, H.E. and Gomma, A.O. (2002). Influence of combined inoculation with diazotrophs and phosphorus solubilizers on growth, yield and volatile oil content of coriander plant (Coriandrum sativum L.). Bulletin of Faculty of Agriculture, Cairo University 53(1): 93-113.

Ahmad, R., Arshad, M., Zahir, Z.A., Naveed, M., Khalid, M. and Asghar, H.N. (2008). Integrating $\mathrm{N}$-enriched compost with biologically active substances for improvinggrowth and yield of cereals. Pakistan J. Bot.40(1): 283-293.

Ali, S.A., Tomar, R.K.S. and Maurya K.N. (1994). Response of coriander (Coriandrum sativum L.) to irrigations and nutrient levels. Bharatiya Krishi Anusandhan Patrika, 9(4): 241-246.

Anon. (2017). Directorate of Arecanut and Spice Development, Kozhikode, Kerala.

Datta, N., Hore, J.K. and Sarkar, T. (2017). Growth and yield of fenugreek (Trigonella foenum-graecum L.) as influenced by different levels of NPK under new alluvial plains of West Bengal, India. Int.J.Curr.Microbiol. App. Sci.6(9): 2304-2312.

Gupta, S.C. and Gangwar, S. (2012). Effect of molybdenum, iron and microbial inoculants on symbiotic traits, nutrient uptake and yield of chickpea. J. Food Leg. 25(1): 45-49.

Jackson, M.L. 1974. Soil Chemical Analysis. Prentice Hall of India Pvt. Ltd., New Delhi, p. 521.

Jhankar, M., Panda, P.C. and Sethi, D. (2017).
Effect of INM practices on yield, yield attributes and economics of coriander (Coriandrum sativumL.) Int.J.Curr.Microbiol. App. Sci.6(5): 1306-1312.

Kumar, R., Sahay, S., Mishra, P.K. and Kumari, R. (2016). Effect of nitrogen, phosphorus and potash on coriander yield. Environ. Eco.34(1A): 360-364.

Lokhande, S.N., Jogdande, N.D. and Thakare, S.S. (2015). Effect of varying levels of nitrogen and phosphorus on growth and seed yield of coriander (Coriandrum sativum). Pl. Arch.15(1): 57-59.

Matama, P. and Parvatam, G. (2016). Arbuscular mycorrhizal fungi promote enhanced growth, tuberous roots yield and root specific flavour 2-hydroxy-4 methoxybenzaldehyde content of Decalepisha miltonii. Acta Sci. Pol. Hortorumcultus 16(2): 3-10.

Pandey, P., Swami, A. and Bhatt, A.B. (2014). Effect of microbial inoculants of Pseudomonas and VAM on Indian basil (Ocimum sanctum Linn.). Int. J. Life Sci.3(2): 41-45.

Pramanik, K. and Singh, R.K. (2003). Effects of levels and mode of phosphorus, biofertilizers on chick pea under dry condition. Indian J. Agron.48(4): 294296.

Sharma, V. and Abrol, V. (2007). Effect of phosphorus and zinc application on yield and uptake of $\mathrm{P}$ and $\mathrm{Zn}$ by chickpea under rainfed conditions. $J$. Food Leg.20(1): 49-51.

\section{How to cite this article:}

Mathukia. R. K., M.V. Adhithi, K.V. Hirapara and Surya. P. R. 2020. Enhancing Coriander (Coriandrum sativum L.) Yield through Integration of Chemical Fertilizers, Enriched Compost and Biofertilizers. Int.J.Curr.Microbiol.App.Sci. 9(06): 1538-1545.

doi: https://doi.org/10.20546/ijcmas.2020.906.190 